\title{
Editorial
}

\section{Leading questions}

In this second issue of 2011, leading into November when the AAWP will feature 'ethical imaginations' as the central theme of its annual conference, each paper pushes into difficult political, ideological, subjective and psychological territories. Anna Gibbs (Writers, writing and writing programs in the information age) breaks open this issue with the question, 'What does the information age mean for the teaching of writing in university writing programs?' She spells out the reality of the new media: we are living with technologies that not only merge the visual, auditory and textual but make possible online collaborations in virtual space or in real time, and constantly changing potential for computerised generation of text. Even the notion of creative writing comes to seem restrictive, outmoded, inadequate and futile in the face of what is happening from within the new technologies. Through a beautifully nuanced overview of the material and virtual aspects of the traditional paper bound book, Gibbs notes that this is a situation which discloses the complex historicity of all writing.

This issue of TEXT will close with a postcard sent home from this new world, as Marsha Berry (Poetic tweets) reports on experiences of short-form public art using phones and media devices. 'It is easy to feel that we are in a world where everyone clamours for attention while no one listens,' she writes. But such contempt is often born of envy and inhibition. The new short forms in tweeting, for instance, constrained by the limitations of 140 characters, become the midwife to innovative uses of language as well as to the resurgence of old forms like haiku. Japanese mobile phone novels, keitai shousetsu, are an act of both improvisation and dialogue among the young. Berry's 'murder of crows' is a moment where shared experience in time, visual art, text, performance and a commitment public art come together.

Tim Jarvis ( 'Pleasure balks, bliss appears' or 'The apparatus shines like a blade': Towards a theory of a progressive reading praxis in Creative Writing pedagogy) takes aim at the notion of reading-like-a-writer, entering into a debate to which Paul Dawson and Marcelle Freiman have made important recent contributions. At the heart of this debate is the question, 'Should work done in creative writing settings in the Academy attempt the production of blissful experimental work, rather than pleasurable fictions that perpetuate ideological codes?' Jarvis believes the answer is broadly 'yes'. He opts for what he calls 'a kind of destabilising reading': a reading in writing modelled as a loss of control or power, a denial of an authorising position, or proper place from 
which to write. He opts for a space where the interrogation of cultural codes can take place and new, radical codes can be formed: a locus of dissent. Whether Jarvis does provide, via Barthes and de Certeau, a way (another way?) of resolving this question, you will have to decide.

Donna Lee Brien (Pathways into an 'elaborate ecosystem': Ways of categorising the food memoir) deals with the largely unexplored subject of the food memoir. Whether it is writers who chef or chefs who write, we are being fed a steady diet of these memoirs. Brien positions food writing, which is often classed as a practical and even banal journalistic mode as, instead, a mode of literary creative production worthy of extended consideration. Her suggested taxonomy and critical analyses open a new area of research for creative nonfiction.

Sue Joseph also turns to memoir (Supervising life-writing of trauma in a tertiary setting), to that sub-genre where we find the chronicling of personal tragedy. Literary enterprises such as this raise ethical questions for student authors and the academics who supervise them. Much has been written in mainstream media about ethical problems related to veracity in these memoirs but little theory has been produced within academia in addressing the ethical and pedagogical questions for the supervision of life writing on trauma. How might supervisors minimize and manage potential harm that can result from retelling trauma narratives? How does the supervisor negotiate between analysis, support, art-making and therapy in these situations? The two case studies that comprise this discussion bring an immediacy, a particular complexity, and an intimacy to the issues. If psychoanalysis and writing do have a cross-over nexus, what are the possible best practices for a writing supervisor who is not an analyst, and cannot be?

Robin Freeman and Karen Le Rossignol open a related area of discussion around personal writing (Clarifying creative nonfiction through the personal essay). It is form rather than genre that denotes creative nonfiction, they argue. It is thus the unique features of the personal essay, based as it is on doubt, discovery and the writer's personal voice that can be instrumental in teaching creative nonfiction writing to our digitally and socially literate cohorts of students. Montaigne introduced personalised approaches that challenged formal style, and which have influenced writers and essayists from his time onwards. Via the brilliant Barbara Kamler, Philip Gerard and Aldous Huxley, Freeman and Le Rossignol provide some invaluable pointers to supporting students to bring imagination to bear in turning plain reality into artful ideas.

Dominique Hecq ('Oranges and Lemons': Art, therapy, subjectivity) continues the themes of personal writing and the connections between writing and therapy as she confronts self and the dissolution of self in writing about trauma, with her own (fictional) memoir as her case study. Finding a particular form suited to speaking about traumatic loss is, she suggests, the key to personal survival. At the core of her memoir, Hush, is the question of the relationship between artmaking and subjectivity as well as a desire to go beyond psychoanalysis' understanding of subjectivity. Consonant with Lacan's theory of suppléance, writing becomes that which enables the ego to cohere. Writing counters the threat of subjective dissolution through a knotting of the imaginary and the symbolic: metaphoric process and metaphor.

Elizabeth MacFarlane (Metaphor as contagion: Notes on the postscript of JM Coetzee's Elizabeth Costello) takes up these questions of metaphor-in-themaking via her discussion of the last pages of Coetzee's significantly shortlisted novel. MacFarlane writes of that sense of helplessness, isolation and silence in the face of language. Is her reading of Elizabeth Costello the kind of 
destabilising reading Tim Jarvis proposes, or is this yet another kind of reading, one that is wholly indistinguishable from writing? The problem of the relationship between language and the world: whether it works by metaphor or analogy, imagination's leap or reasoning's progress, is central to this discussion, as it was to Dominique Hecq's article.

Mary-Ellen Stringer (Home-spun songs of the subaltern: writing race in fiction) continues the raising of difficult ethical and complex ideological questions for writing and writers: how to write race. As a white writer endeavouring to produce a piece of fiction that features race relations Stringer wades, as she says, into an intellectual and socio-political quagmire. Her novel-in-progress, $A$ Beggar's Garden, features a central interracial relationship between a white mother and her black son who is of African descent. 'Already I am on shaky ground,' Stringer writes, for the fiction is based upon her own transgression: she procreated with a black man. "I have two "mixed-race" daughters of African ancestry (heritage? blood? I never know what to say).' These elements could lend themselves to a gothic rendering, or they could produce a voyeuristic parade of cardboard cut-outs, or worst of all, a mawkishly cute and romanticised vision of the marginalised. As a statement of aims, or more accurately as a statement of the hurdles, challenges, political negotiations and impasses that are there before a word is written, Stringer's discussion is a compelling account of a writer doing just what Tim Jarvis proposes and Elizabeth MacFarlane ponders.

The focus on ethics and practice continues with TEXT Special Issue No 12 (Leadership in writing and the creative arts) edited by Donna Lee Brien. The eight articles included here serve to reveal how little research has been undertaken into leadership in the arts sectors of academia. 'Leadership' is a current catchword of academic discourse, Brien says in her introduction, but 'the term "leadership" has multiple and sometimes contradictory meanings'. The pioneering pieces Brien has gathered indicate how critical is the concept of leadership at a variety of levels and in a variety of domains in creative writing teaching and research. The Special Issue sets an agenda for highly important research in our area in the future.

With this issue of TEXT we farewell a worker who supported the journal for 15 years. As Creative Works editor, Steve Evans steered TEXT's creative publication policy through several eras: from the initial 1990s phase when it was odd, even sacrilegious, to have creative works in an academic journal; to the current moment when creative pieces can have status equal to academic pieces. As an example of how far we have come, in this issue of TEXT Dominique Hecq and Elizabeth MacFarlane base their academic articles overtly on their own creative writing: the creative work is undeniably the research.

TEXT has led the way in foregrounding creative work as research, and Steve Evans forged an impressive path in this regard. His selection of pieces for TEXT has been poised and astute, and his management of refereeing processes has been exemplary. You can make a brilliant reader / dossier for creative writing courses from collecting the poems and stories that Steve gathered in TEXT over his 15 years. They show theory, practice, ethics - and a deep sensibility operating all at once.

Steve's eye and ear, and his gentle understanding and certainty, will be missed. 
TEXT

Vol 15 No 2 October 2011

http://www.textjournal.com.au

Editors: Nigel Krauth \& Kevin Brophy

Text@griffith.edu.au 